\title{
Reality and Practicality: Challenges to Effective Cultural Property Policy on the Ground in Latin America
}

\author{
Donna Yates*
}

\begin{abstract}
Although on-the-ground preservation and policing is a major component of our international efforts to prevent the looting and trafficking of antiquities, the expectation placed on source countries may be beyond their capacity. This dependence on developing world infrastructure and policing may challenge our ability to effectively regulate this illicit trade. Using case studies generated from fieldwork in Belize and Bolivia, this paper discusses a number of these challenges to effective policy and offers some suggestions for future regulatory development.
\end{abstract}

It is exceedingly difficult to develop high-level policy that reflects the diversity of situations in both antiquities source and market countries. There exits an inherent challenge between the globalized and the localized; between high-level regulatory schemes that must apply to all and the needs and capabilities of the locations in which it is applied. Assumptions that must be made about developing states' internal capabilities during the crafting of high-level policy may not produce actionable interventions on the ground. As a result, there are aspects of our international antiquities policy regime that are consistently challenged by the realities of protection and law enforcement in parts of the developing world. Yet, as it stands, antiquities source countries are considered to be our first line of defense against theft and trafficking. In many sensitive developing world situations, our existing

${ }^{\star}$ Trafficking Culture Project, Scottish Centre for Crime and Justice Research, University of Glasgow, Scotland. Email: donna.yates@glasgow.ac.uk

ACKNOWLEDGMENTS: This work was supported by the European Research Council under the European Union's Seventh Framework Programme (FP7/2007-2013)/erc Grant agreement n 283873 gtico, the Leverhulme Trust, and the Fulbright Program. The author would like to thank all of the individuals in Belize and Bolivia who agreed to be interviewed for this project. 
international system of cultural property regulation does little to protect heritage sites in situ or to break up the criminal trafficking networks. If we are to continue to consider source-end protection as a lynchpin of the global combating of the illicit antiquities trade, we need to address these issues directly. We also must consider a greater shift in focus from source-end protection to real and effective market reduction.

In this article I will discuss the on-the-ground experience of cultural property protection in two developing Latin American countries with rich archaeological heritage consisting in part of antiquities and other cultural objects with market appeal: Bolivia and Belize. Although drastically different in size, both countries face similar internal pressures related to violence, insecurity, the continued effect of narcotics production and trafficking economies, and the need to improve the lives of a largely poor citizenry. Both countries have a strong interest in protecting their cultural heritage from an economic standpoint in the form of cultural tourism but also as a component of the maintenance of national identity.

Based on information gathered from interviews conducted with heritage professionals and interested stakeholders during targeted fieldwork in Belize (2014) and Bolivia (2013), I will provide a sketch of the various challenges to the effective protection of heritage and prevention of antiquities trafficking in each context. Using these examples as case studies, I will discuss three points of perceived disconnect between the realities of cultural property protection in certain developing world contexts and the aspirational international system that these practitioners are working within: 1. the burden placed on local law enforcement for site protection and criminal investigation vs. the realities of underfunding, institutional failure, remoteness of sites, and access to training and technology; 2 . a regulatory system that focuses on development and maintenance of international partnerships even when such partnerships neither reflect the geographical orientation of the illicit trade, nor the realities of geopolitical schisms; 3 . the tendency for regulatory development at all levels to focus on cultural property trafficking in isolation rather than as part of a web of interrelated illicit economies that might be best regulated or policed together.

I close with policy suggestions which may help to address the realities of antiquities trafficking and heritage protection in many parts of the developing world.

The goal of this paper is not to critique the construction or the intent of specific regulatory tools, but rather to discuss how certain aspects of our existing system of international antiquities regulation play out on the ground and how they are perceived and experienced by those on the front line in two developing world contexts.

\section{BOLIVIA $^{1}$}

\section{Background}

Bolivia is a landlocked South American state that straddles the high Andean plateau and the western Amazon. About 63 percent of its population of 10.5 million people 
live in urban areas and the rest are spread out over Bolivia's vast rural and often poorly accessible tracts. Bolivia has a remarkably low population density, estimated at about 9.46 people per square kilometer. ${ }^{2}$ Ethnicity is a decisive political and social issue and is a major component of Bolivian identity. The country has a large Indigenous population, with estimates ranging from about 40 percent to over 60 percent of the population, depending on how the question is asked, and the majority of Bolivians who do not identify as Indigenous, identify as Mestizo (as do many people who identify as Indigenous). ${ }^{3}$ Although White Bolivians comprise a small minority of the population, political power was historically concentrated in this group; Bolivia has been considered one of the most racially stratified countries in the Americas.

This began to change in the 1990s when modifications to the law allowed for more Indigenous participation in public life. ${ }^{4}$ In late 2005, after a period of popular protest and the resignation of two presidents, Evo Morales became the country's 99th president, the first to self-identify as Indigenous. His leftist government, which remains in power at the time of writing, has instituted significant changes within nearly all sectors of Bolivian governance, culminating in the passing, in 2009, of an entirely new constitution which refounded the Republic Bolivia as the Plurinational State of Bolivia. ${ }^{5}$ Long-considered to be the poorest country in South America, since Morales' election Bolivia has tripled per capita income in the country and its real GDP growth has been projected at 6.7 percent, the highest it has been in 30 years. ${ }^{6}$ This, coupled with aggressive wealth distribution policies from the Morales government, has led to small but noticeable poverty reduction successes in the country, although Morales' regime is not without considerable external and internal criticism.

The protection of the remains of Bolivia's spectacular ancient and Colonial past is set against this backdrop. Bolivia was the heartland of the Tiwanaku culture, a major player during the Andean Middle Horizon, and the eponymous archaeological zone is both a UNESCO World Heritage site and a core component of national identity. The material remains of this culture, as well as those of the subsequent Inka and Aymara cultures, have historically been in demand on the international antiquities market (although less so than objects from neighboring Peru). Bolivia is also home to numerous Colonial-era churches, many located in very remote or even abandoned villages. These churches often contain art objects: paintings, icons, and silver, the latter being the result of the massive silver mines at Potosí. In recent decades, international demand for sacred Colonial Andean art has grown.

Since 1906 it has been illegal to excavate Bolivian archaeological objects without a government license and illegal to remove them from the country. ${ }^{7}$ Objects of Colonial and Republican art were subsequently added to this ban and, as it stands, it is illegal to buy, sell, and export these objects in all circumstances. All of these objects, be they undiscovered in the ground or hanging in a Colonial church, are considered cultural property of the Bolivian state. Thus, almost every ancient or Colonial Bolivian cultural object on the international art market left Bolivia in violation of the law. ${ }^{8}$ 


\section{Record Keeping}

Looking specifically at the maintenance of records concerning aspects of cultural property we can see how quickly such action as a mandate can fail in the developing world. In Bolivia, all known cultural property of the nation has required government registration since 1961. ${ }^{9}$ This is a two pronged process: individuals or groups who possess cultural objects that fall under the law are required to notify the Ministry of Cultures so that the objects may be registered and the Ministry of Cultures is meant to maintain an office tasked with seeking out registerable objects, for example in remote historic churches. Furthermore all dealers in antiquities are meant to be formally registered with the government and their premises are meant to be regularly inspected. ${ }^{10}$ All of this fits well into the framework set out by the 1970 UNESCO Convention on the Means of Prohibiting and Preventing the Illicit Import, Export and Transfer of Ownership of Cultural Property (1970 UNESCO Convention) ${ }^{11}$ (indeed, many of these laws are post-UNESCO), and were certainly an aspect of Bolivia successfully obtaining a bilateral agreement concerning cultural property import restrictions with the United States. ${ }^{12}$

Yet while this registry system exists on paper, the system is aspirational: it represents a mandate that an under-funded ministerial department in a poor country is unable to meet. Few people voluntarily register cultural property in their possession, a complete dealer list has not been compiled in years, and archaeological store rooms, even at major sites, have not been inventoried. ${ }^{13}$ An exception is the register of cultural property within museums and churches. The files concerning objects in these known heritage structures are extensive which has helped in the recovery of stolen objects in a number of cases. ${ }^{14}$ That said, as is often the case, the success of this registry appears to be associated with the devotion and the continued institutional presence over several decades (remarkable in Bolivia) of an individual who has dedicated himself to this particular task. As of mid-2013, these commendable records only existed on paper and the dedicated individual hoped that they would be digitized someday but was not expecting funding anytime soon. In other words, while these records exist, police, customs agents, and others cannot easily access them.

\section{Policing and Institutions}

In Bolivia police protection and state-level justice remains unavailable to most citizens. In 2012, nearly half of Bolivia's municipalities did not have a judge, 77 percent did not have a prosecutor, and 97 percent did not have a public defender. ${ }^{15}$ Bolivian confidence in the police is one of the lowest in Latin America: only 38.9 percent express confidence in their police force, on par with Mexico (39.9 percent), a country whose police force has one of the worst reputations in the world. Furthermore, 44.8 percent of Bolivians reported that they felt insecure: on par with famouslyinsecure Haiti at 44.2 percent. $^{16}$ 
This feeling of general insecurity in Bolivia results in conflict between communities and the state-level police and justice systems. To use one extreme example, there exists in Bolivia a concept called Justicia Comunitaria (Community Justice), which is informally defined as a pre-Conquest Indigenous system of values, judgment, and consequence that exists alongside the regular state-level justice system. A version of Justicia Comunitaria was enshrined in the 2009 constitution as the right for communities to police themselves according to their own Indigenous belief system. However, Justicia Comunitaria in Bolivia (especially when that particular term is used) is nearly always linked to fatal or near fatal lynching of accused criminals. ${ }^{17}$ These lynchings usually happen in poor communities where petty theft has a devastating effect and where the police are seen as either not present or as criminals themselves. Incidentally, these poor communities, especially rural ones, are also the primary targets for cultural property theft. The majority of recent thefts of Conquest and Colonial artworks from Bolivian churches, some 34 thefts from 2008 to 2012, have occurred in small, poor, rural, Indigenous villages that are, by many accounts, outside of the reach of the state-level authorities. ${ }^{18}$ Many recent accounts of cultural property thefts in these areas include complaints from villagers that it took multiple days for the government to send anyone to investigate the crimes, and lamentations from cultural property investigators that the villages in question are very difficult for them to access.

Recently a limited number of communities have been turning to Justicia Comunitaria to deal with cultural property theft, sometimes with fatal consequences. In early March 2012, two men were lynched in the village of Quila Quila after they were allegedly caught robbing Colonial-era paintings from the local church. They were collectively 'tried', beaten, strangled, and buried behind the church they were said to have robbed. What followed was a multi-day standoff between the community and the police, leading to an assurance that the community would face no charges if they handed over the alleged thieves' bodies. ${ }^{19}$ Bolivian communities believe that their authorities are not competent and are entirely unable to protect their heritage sites.

\section{Crime reporting}

Although the looting and trafficking of antiquities is considered a distinct crime under Bolivian law, and a form of aggravated theft under the penal code, ${ }^{20}$ Bolivia has neither a cultural property/heritage police task force, nor a dedicated point person that coordinates cultural property theft and looting cases between the various government and security agencies that have a stake in the matter. The recent introduction of new heritage law in the country focused more on archaeology and contained no new provisions for crime prevention and policing.

As it stands in Bolivia, when there is a reported case of cultural property theft (usually from a historic church), a warning is issued to Interpol and to Bolivian customs from the relevant body within the Bolivian Ministry of Cultures. This notice 
usually contains details of the theft as well as photos and descriptions of the items that were stolen. That such photos are available is a testament to the dedication of Bolivia's cultural heritage documentation group: most countries are unable to issue such reports. That said, it is unclear to what degree customs agents are made aware of these reports. As of the time of writing there is no database of stolen cultural property that is available to anyone outside of the Ministry of Cultures. When archaeological objects are stolen from the ground, or evidence of looting at an archaeological site is detected, no warning is issued. It is unclear if any central records of incidents of archaeological looting are kept. Archaeologists are often unaware of the scale, scope, and focus of cultural property crime within the country.

As is the case in many developing countries, smuggling is part of Bolivian reality, a fact rarely discussed during international debate over cultural property regulation. A sizable amount of the goods available on the Bolivian market have been smuggled or are illicit to some degree. In recent years anti-corruption measures have been put in place and border agents are better monitored for corruption. However, fake electronics, copied software and DVDs, photocopied books, and any number of other items for which duty has not been paid make their way to Bolivian consumers. La Paz, for example, has a massive maze-like market district referred to as El Mercado Negro (The Black Market), which is indicated on quite a few maps. Every consumer good imaginable is available in the stalls of this part of the city. In the past, it has been reported that some illicit antiquities have been bought and sold there. ${ }^{21}$

Due to financial constraints, it is unlikely that any of this will change any time soon. Because the idea of a certain interpretation of ancient Bolivia has become the core of a Bolivian identity and is supported by the current government, completely reinventing the regulation of Bolivian cultural property seems unlikely. Yet it is possible that, internally, the illicit trafficking of Bolivian cultural objects can be policed alongside other illicit goods. Indeed, this is the situation that already exists, but formalization of the linkage may prove effective.

\section{International relations and antiquities}

Since early 2006 when leftist Evo Morales became president of the country, relations between Bolivia and some antiquities market nations, notably the U.S., have been strained. This has had a direct effect on Bolivia's ability to recover stolen cultural objects. For example, in August of 2013, I was informed that a number of looted Bolivian church items had been found for sale on the internet via U.S.-based dealers. Having checked my own records, I can document the items were available online from at least early December 2012. The thefts of these items occurred in the late 1990s and it is unclear when and how they were imported into the U.S. This, however, was not of specific concern: the objects had all been photographed and documented by Bolivia's Ministry of Cultures and Bolivia could clearly prove that these objects were stolen; return should have been straightforward. 
Yet, U.S. and Bolivian sources stated that extremely poor relations between the countries had caused complete stagnation. Although everyone involved (except, perhaps, the antiquities dealer) knew where these stolen objects where and agreed that they should be seized and returned, the final paperwork needed to put this operation in motion was not able to go through. Both the Bolivians and Americans working on this case had deep respect for their counterparts but felt that they were in a political bind. They were unable to advance bilateral cooperation with a country that their government does not wish to cooperate with. All involved care passionately about Bolivian cultural property and are doing good work under the circumstances, but the circumstances are not good. As of June 2015, over two years later, at least some of these stolen cultural items were still available online. ${ }^{22}$

Theft of cultural property has a profound destabilizing effect on Bolivian communities. Perhaps no case demonstrates that better than that of the famous Coroma textiles, the theft of which inspired the first UNESCO convention-based restrictions on the import of Bolivian cultural objects into the U.S. ${ }^{23}$ This bilateral agreement, sought by the Indigenous community members of Coroma who personally petitioned the U.S. government for intervention, has been hailed as a triumph. The textiles were returned, there were convictions in three countries, and a community's sacred heritage was restored. Yet, despite this bilateral success, the heritage of Coroma is not truly protected by the U.S./Bolivia agreement: the cultural objects mentioned in the previous paragraph, still for sale on the internet and the subject of official stagnation, were stolen from Coroma's conquest-era church in the late 1990s. ${ }^{24}$ Coroma's church was also looted in 2008 and in 2009. ${ }^{25}$

\section{BELIZE26}

\section{Background}

Belize is a small Central American state on the eastern side of the Yucatan Peninsula. Formerly British Honduras until independence in 1981, the country is sparsely populated: 361,000 people in about 23,000 square kilometers for a population density of about 15.7 people per square kilometer. ${ }^{27}$ Despite its small population, Belize is one of the most ethnically diverse countries in the world, with most Belizeans considering themselves to be multiracial. About 34 percent of the population is of mixed Maya and European descent, 25 percent are Kriol, meaning mixed African and (largely) British descent, and both of those groups are racially mixed with other Latin Americans, West Indians, Afro-Amerindians (Garifuna), and increasingly Chinese, East Indians, and low German-speaking Mennonites. Most Belizeans are multi-lingual, speaking English as well as Kriol and, more often than not, Spanish and one or more Maya languages.

Belize's archaeological past is spectacular. It houses numerous major and minor Maya archaeological sites, from small sacred caves to large metropolises. Belizeans encounter archaeological objects and sites in their day-to-day lives and 
archaeological themes appear on everything from the currency and on Belize's most popular brand of beer. The sites are spread throughout the country, but there are major concentrations of sites along Belize's borders with Guatemala and Mexico, making cross-border trafficking a serious concern.

Tourism is a large component of Belize's economy. As the country is located only a short flight from the U.S., is English-speaking, has a currency that is pegged 2:1 to the U.S. dollar, and is filled with exotic natural and archaeological sites, it has positioned itself as an easy adventure holiday for U.S. travelers. Because of this, threats to nature and to archaeology are considered to be threats to the country's economy. Belize was heavily hit by the various waves of archaeological looting in Central America, particularly for carved stone stela in the 1960s, and elaborately painted polychrome pottery up into recent years. The most comprehensive study of looting in Belize was conducted in the early $1980 \mathrm{~s}^{28}$ and the most recent study was undertaken in $1999 .{ }^{29}$

\section{Record Keeping}

Looking at record keeping in Belize, which too is mandated by law, ${ }^{30}$ we can observe the typical developing world situation where a well-trained, credentialed, and devoted but very small archaeological body is stretched too thin to do everything that they would like to. The individual in charge of their library of records plans on digitizing them with the strong hope of making them publically available for free online. However, as of 2014 they lacked the appropriate scanning equipment and, more importantly, lacked the staff needed to accomplish the task. They stated that they would have to do the work themselves, but did not have the time. Interviews with other government-employed professionals indicated that in presentations and internal documents, they were still using various looting, trafficking, arrest, and seizure numbers from as far back as the early $1980 \mathrm{~s}^{31}$ and that the last time such numbers were rounded up was $1999 .{ }^{32}$ Such records have not been specifically kept for no other reason than a lack of staff and a lack of time. That said, Belize has made a big push to try to get citizens to voluntarily register archaeological objects in their possession as mandated by law. ${ }^{33}$

\section{Policing and Institutions}

In 1934, Aldous Huxley wrote, "If the world had any ends [Belize] would certainly be one of them. It is not on the way from anywhere to anywhere else. It has no strategic value. It is all but uninhabited...." ${ }^{34}$ Although harsh, this quote sums up the logistical issues of policing in Belize. Its vast, jungle-covered territory contains very few people, is difficult to monitor making it a haven for illicit activities. About 33 percent of Belize's population is considered to be below the poverty line and the country has an unemployment rate of 23 percent. Gang violence is on the rise in the country, particularly in Belize City. In recent years Belize has had one of 
the highest murder rates in the world, from 6th to 3rd highest, close in ranking to neighbors such as Honduras, El Salvador, and Guatemala. ${ }^{35}$ Rape, violent crime, and burglary rates are also extremely high in Belize. The population has historically held the police in low regard due to increasing violence and a perceived failure of the police to respond to and investigate crimes. ${ }^{36}$

Very few crime or justice studies have focused on Belize and academic evaluation of policing in the country is limited. An exception is a pilot study conducted by Hanson et al. in 2004. At the time they found the Belize Police had a staffing shortfall of 13.4 percent as well as a budgetary shortfall. The police lacked basic resources: police station parking lots resembled salvage yards, vehicles were scarce and barely operational, and the Maritime Unit of this long-coasted Caribbean country had only one functioning boat. Poor infrastructure is an issue: a critical lack of roads (as well as the poor condition of existing roads) and some of the most expensive public utilities in the region discourage various types of monitoring and policing, as well as development.

Belize shares long jungle borders with both Mexico and Guatemala. Because of the density and remoteness of the jungle as well as Belize's small population and small police and defense forces, these borders are relatively open. Interviews with Belize police indicate that police checkpoints are easily avoided "by simply walking through trails in the jungle." 37 This, coupled with its position between South America and the U.S., has increasingly led Belize to become a strategic point in the international trafficking of all sorts of illicit goods, including narcotics and persons. Reports indicate that many of the criminals operating on Belize's borders are former Central American paramilitaries, hired into the cartel support infrastructure and that they are "commonly found better armed than the police." 38

All existing studies on the looting and trafficking of cultural property in Belize ${ }^{39}$ and my own fieldwork, document a clear trans-border element to this type of crime, both historically and into the present day. Large Maya sculptural pieces such as Stela 2 from Machaquilá were looted from Guatemala, carried across the Belize border, and exported to the U.S., in that case via a boat to Florida ${ }^{40}$ Ethnographic work has shown that looting gangs from both Guatemala ${ }^{41}$ and Mexico, ${ }^{42}$ themselves from the peripheries of the periphery in their own countries, have been able to move freely between countries. Belizean looters, too, certainly have operated on whatever side of the border was most advantageous. Especially when it comes to transnational crime, this criminal activity occurs in Belize precisely because it is so difficult to monitor the country's remote borders.

\section{Nested Illicit Economies}

Central America has changed a lot in recent decades. Shifts in the regional localities of the transnational trade in narcotics have inspired a movement southward into areas along Mexico's borders with Guatemala and Belize and down into El Salvador and Honduras. ${ }^{43}$ The specifics of these regional shifts are outside of the scope of 
this paper ${ }^{44}$ but in Belize this has led to a situation where the idea of an antiquitiesspecific focus of either organized or disorganized crime is highly unlikely. Cultural property trafficking is neither profitable enough, nor can it be used to effectively "clean" or launder narcotics money. The cartels have more profitable activities to engage in.

At this time antiquities looting and trafficking in Belize appears to rests within a regionalized collection of illicit economies..$^{45}$ Although antiquities looting specialists may have existed in the past, ${ }^{46}$ looting and trafficking in the present is far more opportunistic. Individuals or groups are willing to commit a number of different illicit activities (e.g. animal poaching, smuggling consumer goods across the border, land encroachment, illegal logging, laundering money for narcotics cartels, etc.) because they see them as viable alternatives to other activities and their environment supports such crimes. In other words people commit certain low-cost crimes if the opportunity to do so arises, especially when the physical and moral consequences of committing such crimes are minor and the crimes, themselves, are perceived as victimless.

An interesting example of this can be seen within the Mennonite communities along Belize's border with Mexico. Ideologically opposed to outside governance, Belize's Mennonites have historically been implicated, often unfairly, in the narcotics trade,${ }^{47}$ trans-border smuggling of a number of goods, illegal demolition of archaeological sites, and the looting and trafficking of antiquities: both in the form of actual looting/transport and in receiving money from looting groups for access to sites on Mennonite land. ${ }^{48}$ Clearly only a limited number Belize's Mennonites are willing to engage in these illicit economies; however, some do see it as a viable alternative to other activities, see little consequence in their behavior, and live in an environment that both encourages financial gain and discourages compliance with external government.

Another example are the so-called "subsistence diggers," recorded in Paredes Maury's work in Guatemala and Matsuda's work in Belize. ${ }^{49}$ While Matsuda's "subsistence diggers" do seem to be primarily focused on archaeological looting, he does connect their activity directly to illegal migration into Belize (and thus a lack of legal work option) as well as illicit overland transport of other goods. Paredes Maury's ethnographic work focused on looting conducted by poor chicle gum collectors in rural Guatemala who would loot archaeological sites to add to their meager income, mostly because they were moving through the deep jungle anyway. Looting was the focus of her work, but she notes that people in the region also supplement their income by poaching endangered animals, participating in illegal logging, and participate in the narcotics trade.

Discussion of antiquities looting as one of many opportunistic illicit activities is common in Central America. A group of Guatemalan archaeological workers I spoke with in 2003 stated that they had looted sites in the past and that they poached a jaguar for its pelt because the opportunity to do so was there. As I spoke to a former looter in Belize 2014, we drove a woman to a certain spot near the 
border so she could carry undeclared meat to her shop in Mexico, a service for which the driver was paid. Former Belizean forestry workers that I interviewed did not see much difference between people they caught looting and, say, people they caught trapping macaws, indicating that these were sometimes the same people.

\section{Thinking Internationally in the Past and Present}

Many of the problems associated with regulating the illicit trade in Maya antiquities via international partnership agreements stem from the fact that modern borders do not follow ancient borders. Although the various ancient Maya polities each had their own distinctive iconographic styles, even those styles cross modern borders. Maya polities also participated in complex trade with each other: just because an artifact is of one style does not mean it was not traded to another region in antiquity. Even when a Maya objects bears the name of a known site (the Maya were, of course, a literate culture), this does not conclusively indicate a modern country of origin as it is clear that such objects were traded over great distances. ${ }^{50}$ It is almost impossible to conclusively determine which modern country a previouslyunknown looted and trafficked Maya artifact came from.

Until the 1970s, looting at Maya sites was focused on stone stela and carved architectural elements (lintels, staircases, etc.), massive pieces that were often cut, thinned, or otherwise mutilated for transport. In 1969, Clemency Coggins published a short article which shone a light on the dark trade in looted stela and inspired public discussion about the pillage of Maya sites. In 1972, as a result of the professional outcry that followed and an acknowledgment that the U.S. was the primary market for looted Maya objects, the U.S. passed Public Law No. 92-587 9 U.S.C. $\$ 2091$ : "Regulation of Importation of Pre-Columbian Monumental or Architectural Sculpture or Murals.” It states:

No pre-Columbian monumental or architectural sculpture or mural which is exported (whether or not such exportation is to the United States) from the country of origin after the effective date of the regulation [...] may be imported into the United States unless the government of the country of origin of such sculpture or mural issues a certificate [...] which certifies that such exportation was not in violation of the laws of that country'. Any piece of pre-Columbian monumental sculpture must have 'satisfactory evidence that such sculpture... was exported from the country of origin on or before the effective date of the regulation.

In other words, unless a valid export permit could be produced, all pre-Columbian murals, sculptures, or architectural pieces were prohibited from entering the U.S.

It is important to note that this law is object-focused not country-focused. A Maya stela stopped at a U.S. border cannot enter the country without a valid export permit and thus "fresh," unprovenanced stela cannot enter the country at all. It does not matter what Central American country that stela came from and it does not matter if the exact country of origin is unknown at the time the stela is detected. The U.S. does not need to determine where it is stolen from to establish 
that a stela is contraband, if it does not have the appropriate paperwork, it cannot enter the country. This law shares some characteristics with the contemporaneous 1973 Convention on International Trade in Endangered Species of Wild Fauna and Flora (CITES), ${ }^{51}$ which, among other things, creates an outright ban on the movement of certain plant and animal species no matter where they came from or where they were seized. The result of this law was the collapse of the U.S. market for Maya stela and architectural pieces. ${ }^{52}$ No one could argue that a "new" stela that appeared on the market without an export permit was legal and no Central American country would ever issue an export permit for an artifact on anything other than a temporary basis.

An unforeseen consequence of the ban on sculpture and architecture was a shift in market demand. After 1972, the U.S. market for Maya stela largely disappeared, but the market for Maya pottery exploded, seemingly because it was not covered by the 1972 law. ${ }^{53}$ It would seem that the appropriate response to this increase in trafficking of looted Maya pottery should have resulted in an object-specific U.S. restriction on the importation of Maya pottery, perhaps in the form of a permit requirement, however that did not happen.

In 1983 the U.S. implemented the 1970 UNESCO Convention via the Convention on Cultural Property Implementation Act (CCPIA). CCPIA gave the president of the U.S. the ability to impose import restrictions on certain cultural objects following a request from another state that is party to the UNESCO Convention and to negotiate and enter into bilateral agreements to this effect. These restrictions are bilateral and country specific. Instead of, say, mandating valid export permits for all Maya pottery no matter the country of origin, the U.S. restricts the import of all Maya pottery from a particular country with which it has an agreement. The problem with this should be clear: looted Maya objects that, inherently, do not have a known modern country of origin can fall through the cracks. ${ }^{54}$

At the time of writing, the U.S. has cultural property agreements in place with all of the Maya countries, although the treaty with Mexico is slightly different and was developed before the U.S. implemented the 1970 UNESCO Convention. ${ }^{55}$ The U.S. and Belize only entered into a cultural property bilateral agreement in 2013, meaning that in the years since the implementation of the UNESCO Convention there was at least one Maya heartland country with no U.S. import restrictions. This allowed for exploitable ambiguity in the import and sale of Maya objects in the U.S. ${ }^{56}$

The destruction to Maya sites associated with the looting of pottery and other small items not covered by the U.S. law of 1972 has devastated the region. Although the looting of stela was destructive, these sculptures are usually stand-alone pieces. Pottery and other smaller items are normally found within caches and tombs located deep within Maya temples and other structures. The trickle-down effect of the switch in market demand towards these smaller objects was the wholesale destruction of thousands of Maya buildings. Almost every known Maya site has been compromised by this wave of looting. 


\section{DISCUSSION}

\section{Burden on Developing Countries' Institutions}

As it stands, most of the financial burden of the on-the-ground policing of the illicit traffic in cultural property rests on the source country in the form of physical protection of archaeological and cultural sites. The existing system places emphasis on stemming the supply of looted antiquities at the source rather than discouraging demand. To a large degree, our current regulatory regime depends on extensive, competent, and well-funded internal protection over market-end disruption. This is reflected in the wording of Articles 5 and 6 of the 1970 UNESCO Convention, mandating that the states party to the convention set up national services with "qualified staff sufficient in number" to carry out documentation, protection, excavation, education, regulation, certification, customs, and policing duties within their territories. While subsequent articles of the 1970 UNESCO Convention call for international collaboration, the internal duty to fund protection operations within source countries is emphasized. Even if this wording is merely an ideal, it evidences a clear focus on disruption at the source and not disruption of either transnational trade or the market. Yet as we have seen with both Bolivia and Belize, such source-end disruption may lay far outside of the logistical and financial capacities of developing countries.

Most major antiquities source countries, such as Belize and Bolivia, are located in the developing world where resources are limited. Although these countries often enact tough anti-trafficking laws with stiff penalties, as is the case with both Bolivia and Belize, when faced with the logistical and financial difficulties inherent in the developing world, such laws prove nearly impossible to enforce. Internal legal mandates to train, maintain, and heavily fund numerous different policing, documentation, and heritage preservation groups in an effort to fend off the inevitable effects of international demand for illicit antiquities are left underfunded in the face of more pressing problems. Such mandates are seen as insurmountable obstacles to both engaging in international discussions concerning antiquities trafficking regulation and to successfully negotiating cultural property agreements.

Furthermore, institutional failures in security-related sectors in the developing world are an impediment to the ideal functioning of existing international trafficking prevention measures. High-level international policy formation tends to assume, at least on paper, that there will be a competent police force on the ground, an adequate customs service to combat smuggling, and a functioning justice system to punish wrongdoers. Yet in many developing countries, such functional and funded institutions are the exception, not the rule.

As can be seen in Bolivia, despite steady improvement in recent years, a sizable portion of the population is unable to access state-level institutions. Police are seen as corrupt and insecurity is the norm. In Belize, police suffer from inadequate equipment, short staffing, and remote jungle covered borders. Although the law is clear 
and antiquities theft and trafficking penalties are steep in both countries, few criminals are ever apprehended. Those that are may languish in judicial limbo for years or be let go simply because these justice systems are working with numbers far above their capacity. Again a key element in our international system for antiquities trafficking prevention, security on the ground, depends on the financial and organizational stability of countries that are rarely financially and organizationally stable.

Bolivia and Belize, like most developing countries face major threats related to internal and international crime. Their ability to deal with those issues is seriously hampered by corruption, inaccessible territory, and limited financial resources. Yet there is a perceived expectation internationally that local police and related institutions should be a key component of our international efforts to regulate the flow of looted antiquities onto the market. This expectation may prevent the apprehension and prosecution of individuals higher up on the antiquities trafficking chain and puts an unfair burden on the victims of antiquities theft. Leaving these and other policing and protection efforts up to source countries does not adequately protect heritage sites, does not adequately protect communities, does not prevent illicit antiquities from entering the market, and does not disrupt the illicit trafficking chain.

\section{Focus on Countries, Not Objects}

The development of international agreements between states, either within the framework of the 1970 UNESCO Convention or outside of it, is at the core of our existing international regulatory regime to combat antiquities trafficking. There are a number of issues that arise when regulation of the illicit antiquities trade is reduced to relations between only two modern states. The most obvious is that the paths that looted cultural objects pass through on their way to the market often include third (or fourth or fifth) states which may or may not have cultural property agreements or favorable relations with the initial source and ultimate market countries. They may have no vested interest in spending scarce policing funds on what they might consider to be someone else's problem.

Yet there are more subtle issues on the ground with heritage site protection based on international agreements. Even when agreement is in place, poor relations between the two countries will stall recovery efforts. This is put in particularly sharp focus when considering the return of cultural property from the U.S. to Bolivia. Although relations between these two countries are unsteady, some sort of continued relationship and ongoing negotiations are required for stolen Bolivian cultural objects either to be prevented from entering the U.S. or to be returned. Thus international relations become the focus, not the objects themselves, and preservation hinges on these relations. This country-specific approach is quite different from an object-specific approach, which would require various proofs of ownership and permits for antiquities to cross borders or enter the market. In other words an object-specific approach requires less negotiation and can continue to function even when international relations sour. 
Furthermore, a country-specific focus can be completely ineffective when dealing with ancient cultures that spanned across several modern states. In the case of many forms of Maya pottery, it is nearly impossible to determine which Central American country a looted piece came from. When such pottery is seized outside of Central America, it is usually unclear which modern state can or should claim it. Even when a Maya pot is intercepted leaving Belize, the origin of the piece is not immediately obvious as it could have passed in that country from either Mexico or Guatemala. This ambiguity can and has been exploited by traffickers. However an object-specific regulatory approach, perhaps modeled after CITES and requiring permits and ownership documentation for all Maya pottery crossing any border, might serve to better control the market for such pieces. Maya pottery without a clear country of origin and a clean export history would be prevented from entering the market country and the market itself.

\section{Cultural Objects in Isolation}

We tend to think of cultural objects as unique. They are the manifestation of the intangibilities of human identity, and it is easy to see why there is an urge to produce legislation that distinguishes cultural property theft from other crimes. While it may be correct to separate the theft and trafficking of such rare goods as antiquities from the mundane "normal" stolen goods, that does not mean that antiquities trafficking is unrelated to other crimes. The trafficking and illicit sale of antiquities may be one of a series of interrelated criminal activities which include the transport and sale of other objects. Likewise, the looting of archaeological sites may be a response to economic instability caused by unrelated crime, such as the encroachment of displaced persons onto protected land due to the activities of drug cartel support economies.

This certainly seems to be an issue in Central America, where antiquities looting appears to be one of a number of illicit border economies that individuals engage in either when opportunity presents itself or out of need. These illicit activities are often conducted by the same people in the same space. Using the example of Belize, designated archaeological sites are often in protected forest zones. These protected zones are also the site of illegal logging and rare wood taking, illicit palm cutting for the international flower market, poaching of jaguars for pelts, taking of rare parrots, protected orchid theft and smuggling, and illegal farmsteading, as well as stopover points for planes involved in narcotics trafficking. To an extent, many of these crimes are policed together on the ground by forestry workers and tourism police, but administratively they are differentiated from antiquities trafficking and exist in a separate place within national law and our international regulatory regime. A reduction in illegal farming activities might reduce archaeological site looting; a crackdown on, specifically, parrot smuggling might result in individuals turning to artifact smuggling. Siloing national and international policy for what can be seen as related crimes may prevent us from gaining an accurate understanding of the results of our interventions.

To use the example of the village of Quila Quila in Bolivia, we can see a potential outcome of viewing cultural property theft as separate from internal instability 
and insecurity. This community, out of a profound sense of insecurity and lack of confidence in the authorities, turned to fatal vigilantly justice to punish cultural property robbers. Although this is an extreme, it illustrates what might be a lack of non-heritage-related development within our cultural property protection regime. Perhaps we should make heritage protection a component of more general policy towards social improvement, not a stand-alone area in which capacity is built but no foundation exists for that capacity to rest on.

\section{SOME POLICY RECOMMENDATIONS FROM THE GROUND}

What, then can be done to improve international policy related to antiquities trafficking? That is not an easy question to answer; however beyond what I have previously discussed, this fieldwork in Bolivia and Belize points to two areas of potential improvement.

First, object-focused import restrictions should be promoted. Banning the import of all permit-less Pre-Columbian sculptural pieces, no matter their country of origin, nearly eliminated the market for such items in the U.S. This can and should be done on a global scale, perhaps using CITES as a model. CITES has its flaws, but by banning the free movement of certain animals and plants, no matter their country of origin, many of the exploitable aspects of other types of regulation are avoided. Mandatory export and import permits will go a long way to eliminating traffickers' ability to "clean" illicit antiquities for the more "respectable" market. There will be no "respectable" illicit antiquities and the reduction in demand will naturally reduce motivation to loot for supply.

Second, we should emphasize policing and punishment of traffickers and buyers rather than spend time and money on the return of a limited number of cultural objects. If we accept that most people in developing countries who engage in looting are doing so because of a lack of viable alternatives and as part of any number of illicit and licit short-term economic activities, it is clear that focusing policing and punishment on them is useless. The more powerful end of the market will find other desperate people to commit those crimes. Instead of policy focused on asset return, we need policy focused on reducing the market. This means real punishment for collectors and museums found to be buying looted goods and this means breaking up networks. Any future international regulation should still mandate international cooperation, but that cooperation should be policing- and enforcement-focused.

\section{ENDNOTES}

1. In July and August of 2013, I conducted fieldwork in the La Paz Department of Bolivia. Funded by the Fulbright, this work was focused on cultural property trafficking out of Bolivia, specifically looking at the on-the-ground effectiveness of certain national and international regulation. I also conducted archaeological fieldwork at Tiwanaku, Bolivia, in 2004 and in 2005.

2. Estado Plurinacional de Bolivia 2012. 
3. Carlos Valdez, “Bolivia's Census Omits 'Mestizo’ as Category,” Associated Press, 21 November 2012, http://web.archive.org/web/20150614101606/http://bigstory.ap.org/article/bolivias-census-omitsmestizo-category; Estado Plurinacional de Bolivia 2013.

4. Particularly the 1994 Law of Popular Participation, Law 1551, (1994) (Bol).

5. BOL. CONST. (2009).

6. IMF, "IMF Executive Board Concludes 2013 Article IV Consultation with Bolivia," International Monetary Fund Press Release, 2014, http://web.archive.org/web/20150614100428/https:// www.imf.org/external/np/sec/pr/2014/pr1445.htm (accessed 10 June 2015).

7. Law of 3 Oct. (1906) (Bol.)

8. See Yates 2011 and Yates 2012a for complete analysis of Bolivian cultural property legislation.

9. First via Res. Min. Educación 1642 (1961) (Bol.), then formalized via BOL. CONST. (1967) art. 191. See Yates 2011.

10. “No hay control en los anticuarios de La Paz," La Razón, 5 November 2012, http://web.archive.org/ web/20150614101001/http://www.la-razon.com/index.php?_url=/suplementos/informe/controlanticuarios-Paz_0_1716428483.html (accessed 10 June 2015).

11. Adopted 17 November 1970, entered into force 24 April 1972.

12. 66 FR 63490-63499 (7 December 2011).

13. La Razón 2012. During interviews related to this work, I discovered that artefacts that I personally excavated in Bolivia at a World Heritage Site in 2004 and 2005 have not been formally inventoried, although I submitted the paperwork and reports required by law. They have sat for ten years in an unsecured shed at the site.

14. E.g. paintings stolen from the church at San Andrés de Machaca, see Yates 2015b.

15. Consejo de Derechos Humanos 2013.

16. Ciudadanía \& LAPOP 2012, 106.

17. See Yates 2014.

18. Yates 2014.

19. Henry Aria Gutiérrez, "Linchamientos en Quila Quila," Correo Del Sur, 8 March 2012, http://web.archive.org/web/20150614095536/http://www.infodecom.net/nacionales/chuquisaca/ item/2094-linchamientos-en-quila-quila (accessed 10 June 2015); “Turba linchó a dos supestos delincuentes en Quila Quila,” El Diario, 8 March 2012.

20. DL No 10426 Códifo Penal Art 223, Art 326, Art 358 (2010) (BOL).

21. I have not seen clear proof of this, however I was offered illicit fossils there in 2013. Fossils are protected by the same legislation as antiquities in Bolivia and their sale and transnational transport is prohibited.

22. The specifics of this case have been omitted as the investigation is ongoing.

23. 54 FR 10618-10620 14 March 1989; Lobo 1991; Yates 2012b.

24. According to documentation supplied by informants.

25. "Roban tres cuadros coloniales y escultura de iglesia en Bolivia," ACI Prensa, 26 July 2009, http:// web.archive.org/web/20150614095016/https://www.aciprensa.com/noticias/roban-tres-cuadroscoloniales-y-escultura-de-iglesia-en-bolivia/ (accessed 10 June 2015); Ronald Barrancos, "Bolivia: Robaron 18 Piezas de Platería del Templo San Francisco de Población de Coroma Potosí,” Blog of the Brazilian Ministry of Culture, 25 April 2008, http://blogs.cultura.gov.br/mercosur/2008/05/08/ boliviarobaron-18-piezas-de-plateria-del-templo-san-francisco-de-la-poblacion-de-coroma-potosi/ (accessed 10 June 2015).

26. In July of 2014, I conducted preliminary fieldwork in Belize. Funded by the Leverhulme Trust, this work was focused on cross-border illicit trade between Belize, Guatemala, and Mexico with an emphasis on cultural property trafficking. I also conducted archaeological fieldwork in Belize and along the Guatemalan side of the border in 2003.

27. Statistical Institute of Belize 2015.

28. Gutchen 1983.

29. Gilgan 2000.

30. Ibid.; Gutchen 1983. 
31. Gutchen 1983.

32. Gilgan 2000.

33. Ch 259 Ancient Monuments and Antiquities 6.1 (1972) (BELIZE).

34. Huxley 1934.

35. UNODC 2014.

36. Hanson et al. 2004, 255.

37. Ibid, 252.

38. Ibid.

39. E.g. Gilgan 2000; Gutchen 1983; Matsuda 1998a, 1998b; Pendergast 1991; Pendergast and Graham 1981.

40. U.S. v. Hollinshead 1974, 495 F.2d 1154, 9th Cir.

41. Paredes Maury 1999.

42. Confidential interviews, Belize 2014.

43. Steven Dudley, "The Zetas in Guatemala," Insight Crime Report, 8 September 2011, 3; McSweeney et al. 2014, 489.

44. See Yates 2015a.

45. This information is compiled from confidential interviews conducted in July 2014.

46. As asserted in Matsuda 1998a and 1998b.

47. E.g. Ricardo Flores, "Belize, nueva ruta de narcos operan por tierra y aire," La Prensa Grafica, 12 June 2012, http://web.archive.org/web/20150614100626/http://www.laprensagrafica.com/elsalvador/judicial/267618-belice-nueva-ruta-de-narcosoperan-por-tierra-y-aire (accessed 10 June 2015); I have seen alleged air strips in Mennonite areas and several informants recounted such involvement.

48. Confidential interviews, 2014.

49. Matsuda 1998a, 1998b; Paredes Maury 1999.

50. A spectacular example of this comes from the work of Reents-Budet on Belize's "Buenavista Vase" in Schele et al. 1994.

51. Adopted 3 March 1973, entered into force 1 July 1975.

52. Coggins 1998, 54.

53. Ibid.

54. Gilgan 2000.

55. Treaty of cooperation providing for the recovery and return of stolen archaeological historical and cultural properties, U.S.-Mex., 17 July 1970, 22 UST 494.

56. Gilgan 2001.

\section{BIBLIOGRAPHY}

Ciudadanía \& LAPOP. 2012. "Cultura política de la democracia en Bolivia, 2012: Hacia la igualdad de oportunidades," http://www.vanderbilt.edu/lapop/bolivia/Bolivia-2012-Report.pdf (accessed 10 June 2015).

Coggins, Clemency C. 1969. "Illicit Traffic of Pre-Columbian Antiquities." Art Journal 29, no. 1: 94, 96, 98, 114.

1998. "United Stated Cultural Property Legislation: Observations of a Combatant." International Journal of Cultural Property 7, no. 1: 52-68.

Consejo de Derechos Humanos. 2013. Informe Anual de la Alta Comisionada de las Naciones Unidas para los Derechos Humanos en Bolivia. Report prepared for the General Assembly of the United Nations, 18 February.

Estado Plurinacional de Bolivia. 2012. Boletín Informativo Censo Nacional de Población y Vivienda 2012. No 2, http://www.ine.gob.bo/pdf/boletin/NP_2013_2.pdf (accessed 10 June 2015). 
2013. Bolivia: Characterísticas de Población y Vivienda. Censo Nacional de Población y Vivienda 2012. Instituto Nacional de Estadística, http://www.ine.gob.bo:8081/censo2012/PDF/ resultadosCPV2012.pdf OR http://perma.cc/S3B9-2GNP (accessed 10 June 2015).

Gilgan, Elizabeth. 2000. “Archaeological Heritage Management in Belize: A Case Study.” MA diss., Department of Archaeology, Boston University.

- 2001. "Looting and the Market for Maya Objects: A Belizean Perspective." In Trade in Illicit Antiquities: The Destruction of the World's Archaeological Heritage, edited by Neil Brodie, Jennifer Doole and Colin Renfrew, 73-87. Cambridge: Macdonald Institute.

Gutchen, Mark A. 1983. "The Destruction of Archaeological Resources in Belize, Central America." Journal of Field Archaeology 10, no. 2: 217-27.

Hanson, Robert, Greg Warchol, and Linda Zupan. 2004. "Policing Paradise: Law and Disorder in Belize." Police Practice and Research 5, no. 3: 241-57.

Huxley, Aldous. 1934. Beyond the Mexique Bay. London: Chatto and Windus.

Lobo, Susan. 1991. "The Fabric of Life: Repatriating the sacred Coroma textiles." Cultural Survival Quarterly 15, no. 3, http://web.archive.org/web/20150614100825/http://www.culturalsurvival. org/publications/cultural-survival-quarterly/bolivia/fabric-life-repatriating-sacred-coroma-textiles (accessed 10 June 2015).

Matsuda, David J. 1998a. "The Ethics of Archaeology, Subsistence Digging, and Artifact Looting in Latin America: Point, Muted Counterpoint." International Journal of Cultural Property 7, no. 1: 87-97.

—. 1998b. "Subsistence Digging in and Around Belize." PhD diss., Union Institute, Cincinnati, OH.

McSweeney, Kendra, Erik A. Nielsen, Matthew J. Taylor, David J. Wrathall, Zoe Pearson, Ophelia Wang, and Spencer T. Plumb. 2014. "Drug Policy as Conservation Policy: Narco-Deforestation." Science 343, no. 6170: 489-90.

Paredes Maury, Sofia. 1999. "Surviving in the Rainforest: The Realities of Looting in the Rural Villages of El Petén, Guatemala." FAMSI Reports, http://web.archive.org/web/20150614101208/http://www. famsi.org/reports/95096/95096ParedesMaury01.pdf (accessed 10 June 2015).

Pendergast, David. 1991. “And the Loot Goes On: Winning Some Battles, But Not the War.” Journal of Field Archaeology 18, no. 1: 89-95.

Pendergast, David, and Elizabeth Graham. 1981. "Fighting a Looting Battle: Xunantunich Belize.” Archaeology 34, no. 4: 12-19.

Reents-Budet, Dorie, Linda Schele, Justin Kerr, and Michael Mezzatesta. 1994. Painting the Maya Universe: Royal Ceramics of the Classic Period. Durham, NC: Duke University Press.

Statistical Institute of Belize. 2015. Statistics of the Nation, http://www.sib.org.bz/ (accessed 10 June 2015).

UNODC. 2014. Global Study on Homicide 2013. Vienna: United Nations Publications, https://www. unodc.org/documents/gsh/pdfs/2014_GLOBAL_HOMICIDE_BOOK_web.pdf (accessed 10 June 2015).

Yates, Donna. 2011. "Archaeology and Autonomies: The Legal Framework of Heritage Management in a New Bolivia.” International Journal of Cultural Property 18, no. 3: 291-307. 
2012a. "Archaeological Practice and Political Change: Transitions and Transformations in the Use of the Past in Nationalist, Neoliberal and Indigenous Bolivia." PhD diss., Department of Archaeology, University of Cambridge.

. 2012b. "Coroma Textiles." Trafficking Culture, http://web.archive.org/web/20150614104022/ http://traffickingculture.org/encyclopedia/case-studies/coroma-textiles/ (accessed 10 June 2015).

. 2014. "Church theft, insecurity, and community justice: the reality of source-end regulation of the market for illicit Bolivian cultural objects." European Journal on Criminal Policy and Research 20, no. 4: 445-57.

2015a. "Displacement, deforestation, and drugs: antiquities trafficking and the narcotics support economies of Guatemala." In Cultural Property Crimes: an overview and analysis on contemporary perspectives and trends, edited by Joris Kila and Marc Balcells, 23-36. Brill: Leiden.

. 2015b. "San Andrés de Machaca Church Looting." Trafficking Culture, http://web. archive.org/web/20150614104156/http://traffickingculture.org/encyclopedia/case-studies/sanandres-de-machaca-church-looting/ (accessed 10 June 2015). 